\title{
Corrigendum: Equatorial jet in the lower to middle cloud layer of Venus revealed by Akatsuki
}

Takeshi Horinouchi, Shin-ya Murakami, Takehiko Satoh, Javier Peralta, Kazunori Ogohara, Toru Kouyama, Takeshi Imamura, Hiroki Kashimura, Sanjay S. Limaye, Kevin McGouldrick, Masato Nakamura, Takao M. Sato, Ko-ichiro Sugiyama, Masahiro Takagi, Shigeto Watanabe, Manabu Yamada, Atsushi Yamazaki and Eliot F. Young

Nature Geoscience 10, 646-651 (2017); published online 28 August 2017; corrected after print 29 August 2017.

In the version of this Article originally published, the directional labels on the $x$-axes of Figures 1a-d and $2 \mathrm{a}$ were $\mathrm{W}$ (west), when they should have been $\mathrm{E}$ (east). In Figures $2 \mathrm{~b}, 4 \mathrm{a}, \mathrm{b}$ and $5 \mathrm{a}-\mathrm{c}$, the $x$-axes were given as longitude, when they should have been average wind speed. These errors have been corrected in the online version of the Article. 